\title{
Review \\ Hexokinase-2-Linked Glycolytic Overload and Unscheduled Glycolysis-Driver of Insulin Resistance and Development of Vascular Complications of Diabetes
}

\author{
Naila Rabbani ${ }^{1, *}$, Mingzhan Xue ${ }^{2}$ a and Paul J. Thornalley ${ }^{2, *(D)}$ \\ 1 Department of Basic Medical Science, College of Medicine, Qatar University Health, Qatar University, \\ Doha P.O. Box 2713, Qatar \\ 2 Diabetes Research Center, Qatar Biomedical Research Institute, Hamad Bin Khalifa University, \\ Qatar Foundation, Doha P.O. Box 34110, Qatar; mxue@hbku.edu.qa \\ * Correspondence: n.rabbani@qu.edu.qa (N.R.); pthornalley@hbku.edu.qa (P.J.T.); Tel.: +974-7479-5649 (N.R.); \\ +974-7090-1635 (P.J.T.)
}

check for updates

Citation: Rabbani, N.; Xue, M.; Thornalley, P.J. Hexokinase-2-Linked Glycolytic Overload and Unscheduled Glycolysis-Driver of Insulin Resistance and Development of Vascular Complications of Diabetes. Int. J. Mol. Sci. 2022, 23, 2165. https://doi.org/10.3390/ ijms23042165

Academic Editor:

Dumitru Constantin-Teodosiu

Received: 9 January 2022

Accepted: 14 February 2022

Published: 16 February 2022

Publisher's Note: MDPI stays neutral with regard to jurisdictional claims in published maps and institutional affiliations.

Copyright: (C) 2022 by the authors. Licensee MDPI, Basel, Switzerland. This article is an open access article distributed under the terms and conditions of the Creative Commons Attribution (CC BY) license (https:// creativecommons.org/licenses/by/ $4.0 /)$.

\begin{abstract}
The recent discovery of the glucose-induced stabilization of hexokinase-2 (HK2) to proteolysis in cell dysfunction in model hyperglycemia has revealed a likely key initiating factor contributing to the development of insulin resistance and vascular complications in diabetes. Consequently, the increased flux of glucose metabolism without a change in the expression and activity of glycolytic enzymes produces a wave of increased glycolytic intermediates driving mitochondrial dysfunction and increased reactive oxygen species (ROS) formation, the activation of hexosamine and protein kinase $\mathrm{C}$ pathways, the increased formation of methylglyoxal-producing dicarbonyl stress, and the activation of the unfolded protein response. This is called HK2-linked glycolytic overload and unscheduled glycolysis. The conditions required to sustain this are GLUT1 and/or GLUT3 glucose uptake and the expression of HK2. A metabolic biomarker of its occurrence is the abnormally increased deposition of glycogen, which is produced by metabolic channeling when HK2 becomes detached from mitochondria. These conditions and metabolic consequences are found in the vasculature, kidneys, retina, peripheral nerves, and early-stage embryo development in diabetes and likely sustain the development of diabetic vascular complications and embryopathy. In insulin resistance, HK2-linked unscheduled glycolysis may also be established in skeletal muscle and adipose tissue. This may explain the increased glucose disposal by skeletal uptake in the fasting phase in patients with type 2 diabetes mellitus, compared to healthy controls, and the presence of insulin resistance in patients with type 1 diabetes mellitus. Importantly, glyoxalase 1 inducer-trans-resveratrol and hesperetin in combination (tRES-HESP) — corrected HK2-linked glycolytic overload and unscheduled glycolysis and reversed insulin resistance and improved vascular inflammation in overweight and obese subjects in clinical trial. Further studies are now required to evaluate tRES-HESP for the prevention and reversal of early-stage type 2 diabetes and for the treatment of the vascular complications of diabetes.
\end{abstract}

Keywords: hexokinase-2; hyperglycemia; glycolysis; diabetes; diabetic complications; insulin resistance; methylglyoxal; glyoxalase 1

\section{Introduction: Human Hexokinase-2-Overview of Molecular Characteristics and Subcellular and Tissue Expression}

Hexokinase-2 (HK2; EC:2.7.1.1) is one of four isozymes of hexokinase in mammalian metabolism that catalyze the first step of glucose metabolism, the conversion of glucose to glucose-6-phosphate (G6P): Glucose + MgATP $\rightarrow$ G6P + MgADP. That is, hexokinases interact with glucose and the magnesium $\mathrm{Mg}^{2+}$ complex of ATP [1]. Uniquely, HK2 has a second glucose-binding active site [1]. This additional active site contains a degradation motif that binds heat shock protein cognate 70 (HSC70) and directs HK2 for proteolysis by chaperone-mediated autophagy [2]. Human HK2 is a monomeric protein of molecular 
mass $100 \mathrm{kDa}$ and $\mathrm{K}_{\mathrm{M}}$ for glucose of $340 \mu \mathrm{M}$ [1]. HK2 is normally localized mostly to the external surface of mitochondria [3] and is found in the particulate extracts of tissues [4]. The N-terminal domain of HK2 binds to voltage-dependent anion channel protein (VDAC), located within the outer mitochondrial membrane and acting as a conduit for ATP and for the supply of HK2-catalysed reaction $[5,6]$. HK2 is the major isozyme of hexokinase in skeletal muscle and adipose tissue. It also has significant expression, along with hexokinase-1 (HK1), in vascular cells, as well as the kidneys, the retina, and Schwann cells in the peripheral nerves; it is also the major hexokinase isozyme expressed in early-stage embryogenesis $[7,8]$. HK2 has high expression levels in many types of human tumor, together with increased expressions of phosphofructokinase (PFK), other glycolytic enzymes, and glucose-6-phosphate dehydrogenase (G6PD). This supports increased flux through glycolysis for tumor growth without an increase in the intermediates of earlystage glycolysis $[9,10]$. The promoter of HK2 in tumors is often hypomethylated, which is associated with the dysregulation of transcription-including the direct binding of glucose to increase expression [11,12]. Tumor cell lines may exhibit the direct induction of HK2 expression by glucose, whereas non-malignant human cells in primary culture do not $[11,13]$. The use of tumor cell lines to study dysfunctional metabolism in model hyperglycemia may therefore give misleading outcomes. The genetic polymorphism of HK2 was studied as a possible factor linked to the risk of developing type 2 diabetes mellitus (T2DM) in the Finnish population, but no significant association was found [14,15]. A novel genetic polymorphism of HK2 was found in Pima Indians-a Native American tribe with a high prevalence of T2DM-but it displayed no significant association with risk of T2DM [16].

\section{Hexokinase-2-Linked Glycolytic Overload and Unscheduled Glycolysis}

In studies of metabolic dysfunction supporting dicarbonyl stress induced by high glucose concentrations in human aortic endothelial cells and human periodontal ligament fibroblasts in primary culture, we discovered that the increased glucose metabolism driving metabolic dysfunction in model hyperglycemia was mediated by glucose-induced stabilization of HK2 to proteolysis, producing HK2-linked glycolytic overload [13,17]. This was corrected by off-target effects of glyoxalase 1 (Glo1) inducer, trans-resveratrol, and hesperetin in combination (tRES-HESP) [13,17]. In this review, we describe this and evidence that the hypothesis of HK2-linked glycolytic overload and unscheduled glycolysis are likely key initiators of metabolic dysfunction, contributing to the development of vascular complications of diabetes, diabetic embryopathy, and insulin resistance.

During periods of high glucose concentration in the cytosol, the degradation motif of HK2 is masked by increased active site occupancy by glucose. This stabilizes HK2 to proteolysis, increasing HK2 protein abundance and activity $[13,17]$, and increasing flux of glucose metabolism without any change in other glycolytic enzyme activities and expression-generating a wave of increased glycolytic intermediates through early-stage glycolysis. The consequences of this are:

(i) Increased levels of G6P, which displaces HK2 from mitochondria, impairing the disposal of ATP-causing mitochondrial membrane hyperpolarization, mitochondrial dysfunction, and the increased formation of reactive oxygen species (ROS) [3,18-20];

(ii) Increased fructose-6-phosphate and activation of the hexosamine pathway, increasing enzymatic protein glycosylation $[19,20]$;

(iii) Increased formation of glycerol-3-phosphate and formation of diacylglycerol, with the consequent activation of protein kinase C (PKC) $[19,20]$;

(iv) Increased glyceraldehyde-3-phosphate (GA3P) and dihydroxyacetonephosphate (DHAP), leading to the increased formation of methylglyoxal and dicarbonyl stress $[13,19,20]$;

(v) Increased metabolic channeling of G6P for glycogen synthesis as a consequence of the displacement of HK2 from mitochondria [3] (Figure 1). 


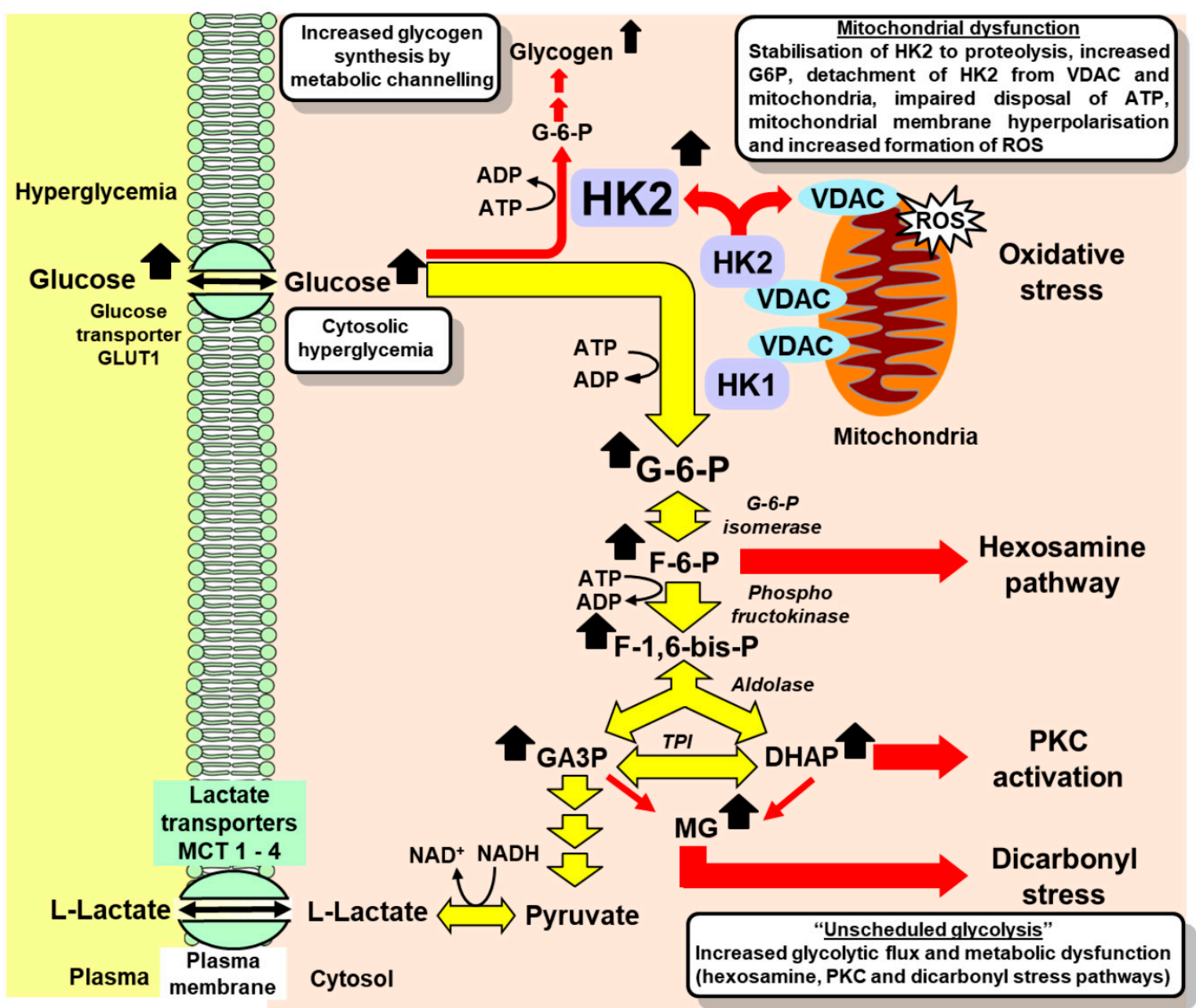

Figure 1. Glycolytic overload and unscheduled glycolysis in hyperglycemia. Key: red arrowsdysfunctional metabolism in unscheduled glycolysis. Metabolic intermediates in glycolysis from GA3P to pyruvate have been omitted for clarity. Abbreviations: DHAP, dihydroxyacetonephosphate; F-6-P, fructose-6-phosphate; F-1,6-bis-P, fructose-1,6-bisphosphate; G-6-P, glucose-6-phosphate; GA3P, glyceraldehyde-3-phosphate; HK1, hexokinase-1; HK2, hexokinase-2; MCT 1-4, monocarboxylate transporters 1-4; MG, methylglyoxal; ROS, reactive oxygen species; VDAC, voltage-dependent anion channel.

In primary cultures of human aortal endothelial cells and periodontal ligament fibroblasts, the flux of glucose metabolism was increased ca. twofold in model hyperglycemia $[13,17]$. A similar effect was found previously in bovine aortal endothelial cells in culture [21].

Under normal metabolic regulation and in short periods of increased plasma glucose concentration, the increased flux of glucose metabolism through glycolysis at sites of vascular complications is restricted by saturation of HK1 and HK2. This also applies for extended periods of increased plasma glucose concentration for tissues with predominantly only HK1 expression-such as the brain. When increased flux of glucose metabolism in skeletal muscle and adipose tissue occurs in response to insulin, regulatory activation and/or the increased expression of glycolytic enzymes occurs such that steady-state levels of glycolytic intermediates remain unchanged or are increased modestly [22]. Responses to insulin include: increased activity of glucose transporter GLUT4, increased expression and activity of HK2, increased activity of 6-phosphofructo-2-kinase/fructose-2,6bisphosphatase (increasing allosteric regulator, fructose-2,6-bisphosphate), and thereby of phosphofructokinase, and increased expression and activity of glyceraldehyde-3-phosphate 
dehydrogenase (GA3PD) [23-26]. With the prolonged increase of glucose metabolism and moderate increases in G6P, the nuclear translocation of the Mondo A/Mlx/G6P transcription factor complex increases the expression of a battery of glycolytic and lipogenic genes with a functional carbohydrate response element (ChRE) [27-29]. This provides a further level of regulation of gene expression in early-stage glycolysis. The paralog protein, Mondo B, or carbohydrate response element binding protein (ChREBP), is dominant in the liver and adipose tissue [30]. Through this regulatory control, an increase in flux in glucose uptake and metabolism occurs without marked increases in G6P, F6P, or triosephosphates [22], avoiding mitochondrial dysfunction and the activation of hexosamine, PKC, and dicarbonyl stress pathways. This is regulated, "scheduled glycolysis", and avoids metabolic dysfunction. By contrast, HK2-linked glycolytic overload is unscheduled glycolysis and the multiple pathways of metabolic dysfunction thereby activated are linked to the vascular complications of diabetes, diabetic embryopathy, and ischemia-reperfusion injury, as reviewed previously [31] and presented below for the first time in relation to insulin resistance.

\section{Hexokinase-2-Linked Glycolytic Overload versus Oxidative Stress as an Initiator of Metabolic Dysfunction in Hyperglycemia}

For ca. 20 years, the "mitochondrial dysfunction-linked oxidative stress in vascular cells with GLUT1-dependent glucose uptake" hypothesis has been the leading hypothesis proposed to explain the initiation of metabolic dysfunction in hyperglycemia driving the development of vascular complications of diabetes [32]. The increased formation of ROS in vascular cells in hyperglycemia also occurs through the activation of vascular NADPH oxidase (NOX) and the increased expression and uncoupling of endothelial nitric oxide synthase (NOS3), stimulated by upstream activation of PKC [33-35]. The hypothesis implicated increased glucose metabolism in hyperglycemia as a driver of mitochondrial and metabolic dysfunction but provided no explanation as to how the saturation of one or both of the two hexokinase isozymes found at the sites of development of vascular complications, HK1 and $\mathrm{HK} 2$, is circumvented. A prediction of this hypothesis was that the antioxidant treatment of vascular complications of diabetes would provide effective therapy. However, clinical trials of the antioxidant treatment of the vascular complications of diabetes have been disappointing, showing no or limited benefits. Examples include vitamin E therapy in the Heart Outcomes Prevention Evaluation (HOPE) and Microvascular Outcomes Prevention Evaluation (MICROHOPE) studies [36] and studies of $\alpha$-lipoic acid in diabetic neuropathy [37]. The hypothesis also provided no explanation for why the peripheral nerves and brain both suffer cytosolic hyperglycemia in diabetes-as indicated by increased $\mathrm{N}_{\mathcal{\varepsilon}}$-fructosyl-lysine content of protein extracts of sciatic nerve and brain in experimental diabetes [38] - but dysfunction and pathogenesis is found predominantly in the neurons of peripheral nerves and not in the brain [39]. The hypothesis of HK2-linked glycolytic overload provides an explanation for all these unresolved features of pathogenic mechanisms and therapy.

In the "HK2-linked glycolytic overload and unscheduled glycolysis" hypothesis, the cytoplasmic hyperglycemia-induced stabilization of HK2 to proteolysis provides the initiating mechanism of increased glucose metabolism, circumventing the substrate saturation of hexokinases (Figure 1). Antioxidant therapy may be ineffective because mitochondrial dysfunction and the formation of ROS are not the initiators of metabolic dysfunction but are rather among multiple downstream effects of the initiating process. Finally, HK2 expression occurs in Schwann cells in peripheral neurons but has very low expression in the neurons of the central nervous system (CNS), providing a rationale for why the brain is resistant and the peripheral nervous system is sensitive to hyperglycemia-induced metabolic dysfunction in diabetes [40,41]. Both peripheral and CNS neurons suffer cytosolic hyperglycemia in diabetes, with GLUT1 and GLUT3 glucose uptake, but only Schwann cells have significant expressions of HK2 and are susceptible to HK2-linked glycolytic overload [31]. Impaired functional support of Schwann cells for axons of peripheral neurons may mediate the development of diabetic neuropathy $[39,42]$. 
In the HK2-linked glycolytic overload and unscheduled glycolysis hypothesis, effective therapy can be provided by decreasing HK2 expression to protein abundance and activity levels found in normoglycemia. This was achieved with tRES-HESP — a synergistic combination of two dietary bioactive compounds optimized to induce the expression of Glo1 via activation and the binding of transcription factor Nrf2 to a functional antioxidant response element (ARE) in the GLO1 gene [43,44]. A further Nrf2-mediated effect was induction of the expression of G6PD-also an ARE-linked gene. This decreases cellular G6P, decreasing the Mondo A/Mlx/G6P-dependent expression of HK2, thereby correcting HK2 protein to normal levels in high glucose concentration (Figure 2). Under treatment with tRES-HESP, human aortal endothelial cells and periodontal ligament fibroblasts were cultured in high glucose concentrations with minimal metabolic dysfunction [13,17]. This offers a new approach for the prevention and treatment of insulin resistance, the vascular complications of diabetes, and diabetic embryopathy.

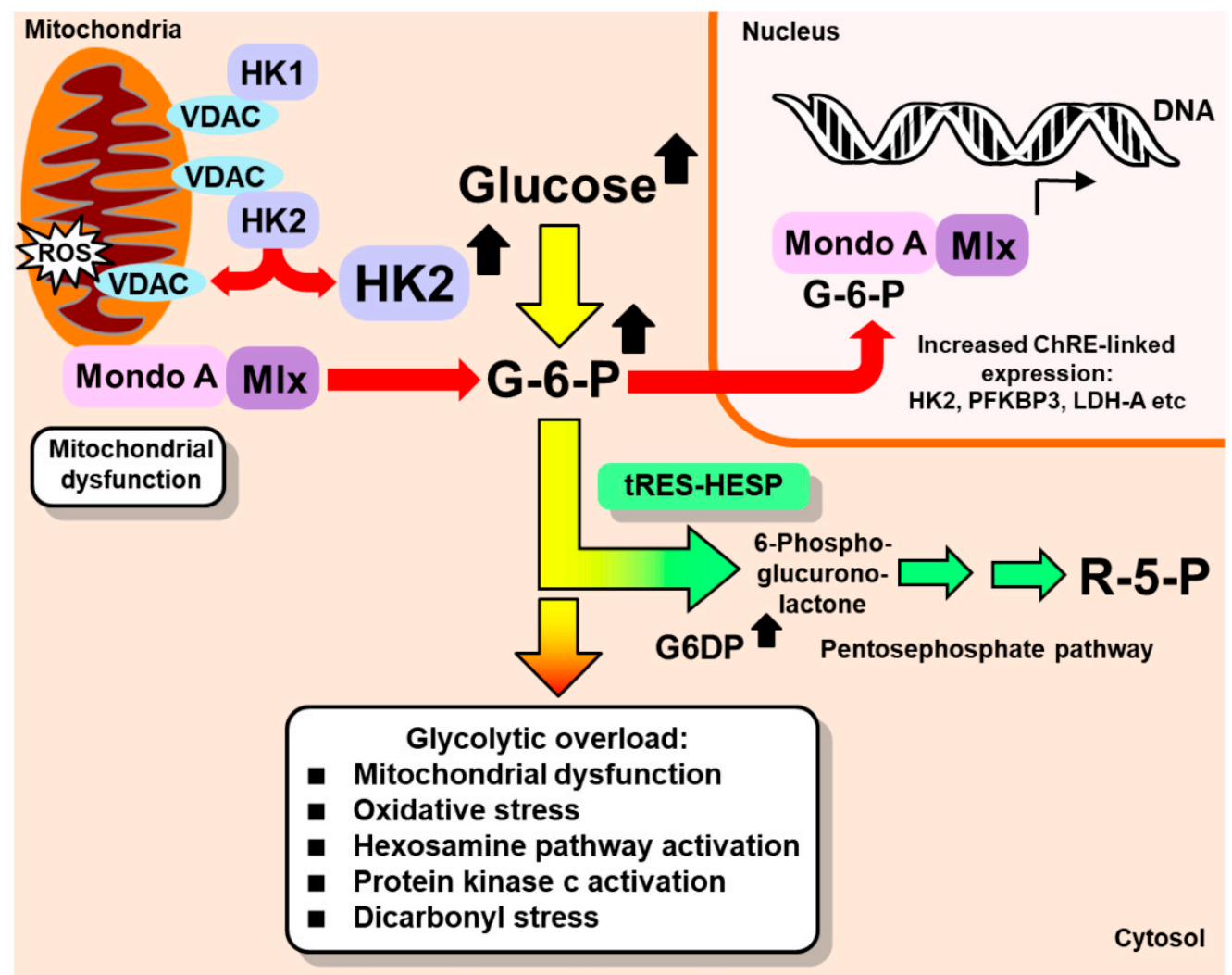

Figure 2. Alleviation of HK-2-linked unscheduled glycolysis by induction of glucose-6-phosphate dehydrogenase expression. Red-tipped arrows: potentially damaging effects; green arrows, Glo1 inducer, tRES-HESP, effect. G6PD, glucose-6-phosphate dehydrogenase; LDH-A, lactic dehydrogenase, isoform A; PFKBP3, 6-phosphofructo-2-kinase/fructose-2,6-bisphosphatase, isoform 3; R5P, ribose-5-phosphate; ROS, reactive oxygen species; VDAC, voltage-dependent anion channel [31].

\section{Evidence of Hexokinase-2 Linked Glycolytic Overload Occurring at Sites of Vascular Complications of Diabetes}

An inspection of previous studies reveals widespread evidence for HK2-linked glycolytic overload involvement in the development of endothelial dysfunction in diabetes, and vascular complications of diabetes - diabetic nephropathy, diabetic retinopathy and diabetic neuropathy, and diabetic embryopathy (Table 1). The increased basal expression of HK2 in dermal fibroblasts cultured from patients with type 1 diabetes mellitus (T1DM) was also linked to the rapid progression of diabetic nephropathy, suggesting that basal HK2 expression may be a risk predictor of the progression of vascular complications of diabetes [45]. The constituent cell types exhibiting the criteria for susceptibility to HK2-linked 
glycolytic overload are: vascular endothelial cells; mesangial cells, podocytes, and tubular epithelial cells of the kidney; endothelial cells, Muller cells, and pericytes of the retina; and Schwann cells of the peripheral nervous system [13,46-49]. Early-stage embryonic cellsup to day 10 post-conception for mouse embryos-have mainly glucose uptake by GLUT1 and GLUT3 and HK2-linked glycolysis [7,50]. From days 2 to 10 post-conception of embryo development, glucose metabolism is mainly anaerobic glycolysis-predisposing embryo development to dysregulation in the early-stage glycolysis during this period [51]. All the features of HK2-linked glycolytic overload have been reported for early-stage embryos in high-glucose concentration cultures and experimental diabetic embryopathy [7,52-55]. There is evidence, therefore, that HK2-linked glycolytic overload occurs at the sites of vascular complications and early-stage embryo in diabetes and this likely contributes to hyperglycemia-linked pathogenesis developing therein in diabetes. Similar pathogenesis, of lower severity, is expected in prediabetes, consistent with the low risk and presence of vascular complications and embryo malformations in prediabetes [56,57].

Table 1. Evidence for hexokinase-driven glycolytic overload and unscheduled glycolysis in insulin resistance, vascular complications of diabetes, and diabetic embryopathy.

\begin{tabular}{|c|c|c|c|}
\hline Pathogenesis & Tissue/Cell Type & Indications & References \\
\hline $\begin{array}{l}\text { Insulin resistance } \\
\text { (skeletal muscle) }\end{array}$ & Skeletal muscle myocytes & $\begin{array}{l}\text { 1. HK2 expression. } \\
\text { 2. Downstream metabolic dysfunction (DS, } \\
\mathrm{HP}, \mathrm{MD}, \mathrm{OS}, \mathrm{PKC})\end{array}$ & [58-62] \\
\hline $\begin{array}{l}\text { Insulin resistance } \\
\text { (adipose tissue) }\end{array}$ & $\begin{array}{l}\text { Adipose tissue, } \\
\text { insulin-resistant 3T3-L1 } \\
\text { adipocytes in vitro }\end{array}$ & $\begin{array}{l}\text { 1. HK2 expression } \\
\text { 2. Increased glycogen deposition in } \\
\text { adipose tissue } \\
\text { 3. Downstream metabolic dysfunction (DS, } \\
\text { MD, OS, PKC) }\end{array}$ & [63-67] \\
\hline $\begin{array}{l}\text { Diabetic endothelial } \\
\text { dysfunction }\end{array}$ & Endothelial cells & $\begin{array}{l}\text { 1. Increased glucose metabolism in } \\
\text { hyperglycemia through stabilization of } \\
\text { HK2 to proteolysis } \\
\text { 2. Glycogen accumulation induced by high } \\
\text { glucose concentration in vitro and } \\
\text { hyperglycemia in vivo } \\
\text { 3. Downstream metabolic dysfunction (DS, } \\
\text { HP, MD, OS, PKC) }\end{array}$ & {$[13,19,20,68]$} \\
\hline Diabetic nephropathy & $\begin{array}{l}\text { Renal mesangial, cells, } \\
\text { podocytes, and tubular } \\
\text { epithelial cells }\end{array}$ & $\begin{array}{l}\text { 1. Increased HK2 protein in human } \\
\text { mesangial cell by high glucose } \\
\text { concentration in vitro } \\
\text { 2. Abnormal glycogen deposition in } \\
\text { proximal and renal tubules } \\
\text { 3. Downstream metabolic dysfunction (DS, } \\
\text { HP, MD, OS, PKC) }\end{array}$ & {$[46,69-73]$} \\
\hline Diabetic neuropathy & $\begin{array}{l}\text { Schwann cells (also dorsal } \\
\text { root ganglia and sciatic nerve) }\end{array}$ & $\begin{array}{l}\text { 1. Increased HK2 in hyperglycemia } \\
\text { 2. Glycogen accumulation in association } \\
\text { with demyelination and axonal } \\
\text { degeneration in clinical } \\
\text { diabetic neuropathy } \\
\text { 3. Downstream metabolic dysfunction (DS, } \\
\text { MD, OS) }\end{array}$ & {$[41,74-78]$} \\
\hline
\end{tabular}


Table 1. Cont.

\begin{tabular}{|c|c|c|c|}
\hline Pathogenesis & Tissue/Cell Type & Indications & References \\
\hline Diabetic retinopathy & $\begin{array}{l}\text { Muller cells, endothelial cells } \\
\text { and pericytes (also } \\
\text { intact retina) }\end{array}$ & $\begin{array}{l}\text { 1. HK2 expression in human retina } \\
\text { 2. Abnormal glycogen accumulation } \\
\text { 3. Downstream metabolic dysfunction (DS, } \\
\text { HP, MD, OS, PKC) }\end{array}$ & {$[47,73,79-82]$} \\
\hline Diabetic embryopathy & $\begin{array}{l}\text { Early-stage embryo (typically } \\
\text { rat embryo, } \\
\text { day } 9-11 \text { gestation) }\end{array}$ & $\begin{array}{l}\text { 1. HK2-dependent glucose metabolism. } \\
\text { 2. Increased embryo glycogen content after } \\
\text { culture in high glucose concentration } \\
\text { in vitro } \\
\text { 3. Downstream metabolic dysfunction (DS, } \\
\text { HP, MD, OS, PKC) }\end{array}$ & {$[7,52-55,83]$} \\
\hline
\end{tabular}

Abbreviations: DS, dicarbonyl stress; HP, hexosamine pathway; MD, mitochondrial dysfunction; OS, oxidative stress; $\mathrm{PKC}$, protein kinase $\mathrm{C}$ pathway.

Increased deposition of glycogen was a surprising mechanistic biomarker of HK2linked glycolytic overload [13]. Increased glycogen deposition was found previously in experimental diabetes in renal proximal and distal tubules, linked to diabetic kidney disease, and in the retina, linked to diabetic retinopathy $[84,85]$. It was also found in Schwann cells in experimental and clinical diabetic neuropathy and linked to severity of nerve damage $[86,87]$. Increased glycogen deposition was also found in corneal neurons in diabetes [88] and in early-stage embryos incubated in high glucose concentrations [83]. Glycogen deposition at the sites of vascular complication in diabetes and early-stage embryogenesis in hyperglycemia linked to pathogenesis has hitherto been an inexplicable phenomenon; now, however, it is a prediction of, and consistent with, the HK2-linked glycolytic overload hypothesis.

\section{Evidence for Hexokinase-2 Linked Unscheduled Glycolysis in Insulin Resistance and the Development of Type 2 Diabetes}

Insulin resistance in skeletal muscle is considered to be the primary initiating metabolic defect driving the development of T2DM; it is often present many years before diabetes develops $[89,90]$. Pancreatic beta-cells respond with compensatory increased secretion of insulin, producing hyperinsulinemia. This stresses beta-cell metabolism, insulin production, and glucose homeostasis. Eventually, the hypersecretion of insulin leads to beta-cell failure, with the development of persistent hyperglycemia and the onset of T2DM. Insulin resistance is defined as "a reduced response of target tissues (to insulin), compared with subjects with normal glucose tolerance" [91]. The main target tissues of insulin are skeletal muscle, liver tissues, and adipocytes. Skeletal muscle is the predominant site of insulin-mediated glucose uptake in the postprandial state. Hence, the dysfunction of glucose uptake and metabolism by skeletal muscle has a major impact on glucose homeostasis [92].

In human skeletal muscle, HK2 is the major hexokinase isozyme-accounting for ca. $60 \%$ of hexokinase activity in the soluble fraction and $90 \%$ hexokinase activity in the particulate fraction bound to mitochondria. Insulin increases the expression of HK2 in skeletal muscle [93] and the binding of HK2 to mitochondria, likely by increasing phosphorylation by protein kinase B-also called Akt [94,95]. HK2 mRNA, protein and activity were decreased in patients with T2DM [96], presumably as a consequence of decreased insulin responsiveness and regulation of HK2 expression. We note that to establish unscheduled glycolysis, it is not necessary for the absolute metabolic flux through glycolysis to be relatively high-which occurs in naïve muscle with insulin treatment [97]. Rather, the critical feature is increased glucose uptake by GLUT1 and metabolism, and glucose-linked proteolysis stabilization of HK2 occurring without other regulatory signaling-such as likely occurs when fasting plasma glucose (FPG) is increased. 
Given the expression of GLUT1 in human skeletal muscle [98,99], muscle may be susceptible to HK2-linked unscheduled glycolysis when FPG is increased; this can thereby initiate metabolic dysfunction, leading to insulin resistance. Supporting evidence is described below.

a. Overexpression of GLUT1 in skeletal-muscle-induced impairment of insulin-responsive glucose uptake

Studies of transgenic mice with overexpression of GLUT1 in skeletal muscle showed there was a 3-4 fold increase in basal glucose uptake and no stimulation of glucose uptake by insulin in skeletal muscle, relative to wild-type control mice, whereas wild-type controls had a 2-3 fold increase in glucose uptake in response to insulin [100]. The investigators, Mueckler et al., commented: "Although blood glucose levels are reduced and fuel metabolism in general is altered in the transgenic animals, we could detect no detrimental effect of these changes on the mice" [100]. On further examination, the same group characterized the mechanism of impaired insulin stimulation of skeletal muscle in GLUT1-overexpressing mice: there was impaired recruitment of GLUT4 for glucose transport by insulin [101]. They explored the mechanism and found that it involved increased hexosamine pathway activity [102]. Increased hexosamine pathway activity is an expected consequence of HK2-linked unscheduled glycolysis [31]. The impaired recruitment of GLUT4 for increased glucose transport in response to insulin is one of the characteristics of clinical insulin resistance [103]. By contrast, the overexpression of GLUT4 enhanced insulin sensitivity [104].

The overexpression of GLUT1 in skeletal muscle is expected to increase the in situ rate of uptake of glucose in the fasting state, mimicking the effect of increased FPG with normal GLUT1 expression. This suggests that increased glucose uptake in the fasting phase, in the absence of increased insulin and recruitment of GLUT4 glucose transporters, may drive the development of impaired GLUT4 responsiveness to insulin-conditions sustaining HK2-linked unscheduled glycolysis.

There is evidence of the decreased expression of GLUT1 in the skeletal muscle of patients with T2DM, but the effect of increased FPG more than compensates for this to produce an increased rate of whole body glucose utilization in the fasting state [99]. It is, perhaps, hitherto surprising that patients with T2DM and insulin resistance may exhibit increased glucose metabolism in skeletal muscle in the fasting state, compared to healthy controls. HK2-linked unscheduled glycolysis explains this.

b. Partial knockdown of hexokinase-2 (HK2 (-/+)) in mice improved glucose tolerance in the late stage of glucose challenge

In mice with heterozygous deletion of $\mathrm{HK} 2$, there were indications of improved glucose tolerance in the late stage of intraperitoneal glucose load. HK2(+/ - ) mice had lower plasma glucose and insulin concentrations at $60 \mathrm{~min}$ after glucose challenge [105]. The benefits of decreased HK2 on the glucose tolerance test are expected to develop at the late stage of the glucose challenge because the stabilization of HK2 by glucose produces a time-dependent increase in HK2 protein abundance linked to metabolic dysfunction. This surprising finding was presented without explanation and requires further investigation. Lower basal levels of HK2 may provide resistance to unscheduled glycolysis. The heterozygous knockdown of HK2 can be viewed as a genetic control to counter the approximate doubling of HK2 in high-glucose concentration-induced unscheduled glycolysis [13,17].

c. Overexpression of hexokinase-2 in skeletal muscle of mice impaired uptake of glucose on a high fat diet in hyperinsulinemic euglycemic clamp studies

Transgenic mice overexpressing HK2 in their skeletal muscle were generated [106]. Subsequent studies with standard and high-fat diet (HFD) feeding [107] showed that fasting blood glucose was increased in HFD compared with standard diet-fed wild-type mice but not in transgenic HK2-overexpressing mice. In hyperinsulinemic euglycemic clamp studies, the index of glucose uptake, $R_{g}$, was reported for gastrocnemius, superficial vastus lateralis and soleus muscle during saline and insulin infusions. There was no difference 
in $R_{g}$ when saline alone was infused, whereas it was increased during insulin infusion in all muscles regardless of genotype or diet. For insulin-stimulated glucose uptake, the overexpression of HK2 increased $\mathrm{R}_{\mathrm{g}}$ in all muscles, compared to wild-type controls, of standard-diet-fed mice. The authors report that HFD feeding "blunted insulin-stimulated $R_{g}$ " and "HK2 overexpression was unable to correct the impaired response". Whilst this is correct, in the HK2 transgenic mice, there was a ca. 60-70\% decrease in $\mathrm{R}_{\mathrm{g}}(p<0.05)$ with HFD feeding, compared to standard-diet feeding, whereas in the wild-type mice, there was a small, ca. 10-30\%, decrease in $\mathrm{R}_{\mathrm{g}}$ with HFD feeding, compared to standard diet feeding with no significance reported-Figure 4 of Ref. [107]. This indicates that HK2 overexpression impaired insulin-stimulated glucose uptake. It may be that the authors did not describe this as it was an unexpected effect, counter to their hypothesis that "impaired muscle glucose uptake resulting from high-fat feeding would be exposed in high flux states and could be corrected by HK2 overexpression" [107]. The concentration of G6P in skeletal muscle was increased in the sedentary state with overexpression of HK2 in the HFD-fed mice [107]. This is consistent with the occurrence of HK2-linked unscheduled glycolysis in the fasting state and the impairment of insulin-stimulated glucose uptake by muscle measured in clamp studies. Increased HK2 expression in the normal diet may improve clamp glucose uptake through high basal levels of glucose phosphorylation together with insulin and other regulatory transcriptional control of glycolytic enzymes.

A further relevant study focused on the skeletal muscle glucose uptake and metabolism in mice with overexpression of both GLUT1 and HK2 in their skeletal muscle. These mice had 3.2 fold increased G6P concentrations and 7.5 fold increased glycogen levels in their skeletal muscle on a standard diet. There was no change in basal or insulin-stimulated whole-body glucose disposal [108]. In this transgenic model, skeletal muscle is chronically exposed to increased G6P, which is expected to induce the increased transcription of glycolytic enzymes through Mondo A/Mlx/G6P signaling. This negates the unscheduled glycolysis that occurs when HK2 abundance occurs without an increase in the transcription and activity of other glycolytic enzymes. In HK2-overexpressing mice (with a 7 fold increase in skeletal muscle HK2 protein [108]), it is expected that there will be a marked increase of HK2 in the cytosol detached from the mitochondria. This non-mitochondrial HK2 increases metabolic channeling for glycogen synthesis in both the fasting and prandial phases $[3,13]$. This may explain the observed increased glycogen deposition in skeletal muscle in this transgenic model.

d. Downstream metabolic signaling in skeletal muscle and adipose tissue in insulin resistance resembles HK2-linked unscheduled glycolysis

The metabolic dysfunction characteristic of HK2-linked unscheduled glycolysis is found in insulin resistance in skeletal muscle: hyperpolarization of mitochondria and increased ROS formation, increased hexosamine pathway activity, and activation of PKC and dicarbonyl stress [58-61]. Similar effects have been recorded in adipose tissue-apart from the activation of the hexosamine pathway [63-67]. For the abnormal deposition of glycogen as a biomarker of HK2-linked unscheduled glycolysis, this is confounded by the decreased insulin signaling in insulin resistance in skeletal muscle and the dysregulation of insulin-stimulated glycogen deposition [91,109]. However, increased glycogen deposition was found in adipose tissue in an animal model of insulin resistance and in clinical obesity $[67,110]$ (Table 1$)$.

Currently, insulin resistance has no well-evidenced and accepted causative mechanism and has been called a "malady without a mechanism" [103]. HK2-linked unscheduled glycolysis may provide a missing contributory mechanism. The current hypotheses of the mechanism of insulin resistance do not explain points a-c above. It has been proposed that glucose entering muscle cells via GLUT4 is only available for glycolysis and glycogen synthesis, whereas glucose entering by GLUT1 is available for other processes contributing to insulin resistance, such as the hexosamine pathway [111]. However, the glucose released from GLUT1 and GLUT4 transporters inside muscle cells is a common glucose pool. The HK2 unscheduled glycolysis hypothesis explains these observations 
through the entry of glucose via GLUT1 independent of insulin, leading to increased HK2 through stabilization to proteolysis and a wave of increased glycolytic intermediates. By contrast, entry of glucose via GLUT4 stimulated by insulin, with a concomitant stimulation of HK2 expression, phosphofructokinase activity, and the expression of other glycolytic and glycogenic enzymes, produces increased flux through glycolysis and glycogen synthesis without marked increases in steady-state glycolytic intermediates-as discussed in [31]. The stabilization of $\mathrm{HK} 2$ to proteolysis with increased glucose metabolism and a related increase in G6P and Mondo A/Mlx/G6P signaling may play a key role in the nutrient sensing of skeletal muscle in fasting and insulin-resistant states. Indeed, Mondo A is also known to be a contributary factor to the development of insulin resistance through its increasing of the expression of thioredoxin interacting protein (TXNIP) [112], impairment of insulin signaling, and increasing of lipogenesis [113,114].

From the hypothesis of HK2-linked unscheduled glycolysis in the development of insulin resistance, two key predictions follow.

Prediction 1. Increased fasting plasma glucose concentration is an expected risk predictor for the development of insulin resistance and T2DM.

There is, indeed, clinical evidence to support this. Increase in FPGs measured approximately 3 years apart was a risk predictor of development of increased insulin resistance and T2DM, independent of change in $2 \mathrm{~h}$ plasma glucose in an oral glucose tolerance test [115]. FPG was also linked to both hepatic and extrahepatic insulin resistance [116].

Prediction 2. Insulin resistance is an expected characteristic of subjects with increased fasting plasma glucose, including patients with T1DM.

The increased FPG found in patients with T1DM is expected to induce insulin resistance. Indeed, studies by DeFronzo et al. found that insulin resistance was a prominent feature of patients with T1DM, linked mainly to insulin resistance in peripheral tissues, particularly skeletal muscle [92,117]. This was independent of changes in the insulinsensitizing hormone, adiponectin [118]. Hitherto, no explanation has been proposed for this.

Further studies are now required to explore evidence for this hypothesis. A related new approach to the treatment of insulin resistance is tRES-HESP, which corrects HK2linked unscheduled glycolysis [13,17]. In overweight and obese subjects in the Healthy Aging Through Functional Food (HATFF) clinical trial [44], this treatment corrected insulin resistance and therefore offers a new route to the prevention, reversal, and treatment of T2DM.

\section{How May Glyoxalase 1 Inducer, trans-Resveratrol, and Hesperetin Prevent the Development of Vascular Complications of Diabetes and Correct Insulin Resistance in Skeletal Muscle and Adipose Tissue?}

tRES-HESP was developed through the optimization of the induction of Glo1 expression using a screen of dietary bioactive compounds and synergistic combinations, thereby activating Nrf2 and increasing Glo1 transcription by binding to a functional ARE of the GLO1 gene $[43,44]$. Increased concentrations of MG and MG-mediated protein glycation produce increased misfolding of proteins and activation of the unfolded protein response (UPR) $[13,17,119]$. Protein glycation by MG is particularly damaging because it often occurs in the functional sites of proteins, producing misfolding and inactivation. It also targets chaperonin complexes and proteasome subunits, which are required for correct protein folding and removal of damaged proteins, respectively. That is, protein glycation by MG also impairs the activities of proteins that correct misfolding or target degradationmisfolded proteins [13]. Further evidence of the impact of MG on protein misfolding includes the increased Golgi-to-endoplasmic reticulum retrograde transport and ubiquitin E3 ligases involved in misfolded protein degradation in fibroblasts under dicarbonyl stress in high glucose concentrations [17], likely supporting endoplasmic reticulum-associated protein degradation of misfolded proteins in the UPR [119]. The prevention of protein 
glycation by MG by increasing the expression of Glo1 is a therapeutic strategy to prevent and slow the development of the vascular complications of diabetes, as reviewed in [120]. However, in correcting HK2-linked glycolytic overload, tRES-HESP may have a more profound therapeutic response by normalizing multiple pathways of metabolic dysfunction in high glucose concentration by addressing the initiating source of biochemical dysfunction (Figures 1 and 2). For example, with tRES-HESP treatment, human aortal endothelial cells maintained normal levels of glucose metabolism when cultured in high glucose concentrations [13]. No other treatment previously proposed for the vascular complications of diabetes produced this. This new approach to therapy may be more effective because it addresses the likely initiating mechanism of the hyperglycemia-linked mechanisms contributing to the development of the vascular complications of diabetes.

From the hypothesized contribution of HK2-linked unscheduled glycolysis to the development of insulin resistance, the activation of the UPR provides a key contributory role, increasing the expression of established mediators of insulin resistance, TXNIP and tumor necrosis factor- $\alpha(\mathrm{TNF} \alpha)$. In UPR activation, inositol requiring enzyme- $1 \alpha$ (IRE1 $\alpha)$ stabilizes TXNIP mRNA to increase its expression and activity [121]. TXNIP decreases glucose uptake by GLUT4 in skeletal muscle, pancreatic beta-cell mass, and insulin secretion, and increases hepatic gluconeogenesis [122-124]. Inflammatory signaling mediated through $\mathrm{X}$ box-binding protein 1 (XBP1) of the UPR increases histone $\mathrm{H} 3$ lysine 4 methyltransferase, SET7 $/ 9$, increasing the expression of p65 in the NF- $\mathrm{kB}$ system and inflammatory mediators $[125,126]$, including TNF $\alpha$ - a key contributor to insulin resistance in skeletal muscle $[127,128]$. The correction of insulin resistance by tRES-HESP in overweight and obese subjects in the HATFF study correlated with improvements in the expression of TXNIP and TNF $\alpha$ [129].

tRES-HESP also increased the expression of G6PD, decreasing cellular levels of G6P, thereby decreasing the transcriptional action of Mondo A/Mlx/G6P and the expression of HK2 [13]. If HK2-linked unscheduled glycolysis contributes to insulin resistance, decreases in HK2 expression are expected to decrease insulin resistance and improve glucose tolerance. Decreases in Mondo A/Mlx/G6P transcriptional activity are also expected to decrease the expression of other ChRE-linked genes-TXNIP, lipogenic enzymes, and others (Figure 2)—which may improve glucose tolerance and decrease insulin resistance $[113,130]$. Interestingly, functional genomic studies with tissue-selective activation of Nrf2 (by partial knockdown of Keap1) in the obesogenic HFD-fed mouse model of insulin resistance indicated that the selective activation of Nrf2 in skeletal muscle and the liver corrected insulin resistance and dysglycemia, respectively [131]. There is the expectation, therefore, that the activation of Nrf2 by tRES-HESP will also produce both of these responses, which was found in the HATFF study [44].

We have proposed that tRES and HESP synergize to activate Nrf2 through the upstream inhibition of phosphodiesterase (PDE) [132] and the activation of protein kinase A (PKA) [133], respectively (Figure 3). The Nrf2 system is a constitutive translocational oscillator, with oscillations of Nrf2 moving in and out of the cell nucleus, increasing in frequency when activated [134]. HESP likely drives increased Nrf2 oscillation frequency through the activation of PKA and Fyn kinase downstream at $\geq 1 \mu \mathrm{M}[44,133,135]$, and tRES decreases the acetylation-driven nuclear inactivation of Nrf2 by increasing in situ activity by inhibiting cAMP phosphodiesterases, activating AMP-activated protein kinase (AMPK), and increasing NAD ${ }^{+}$and the in situ activity of sirtuin-1 [132], with HESP also synergizing for AMPK activation and sirtuin-1 through the PKA pathway $[132,133,136]$.

There are multiple pharmacological synergisms of tRES and HESP, including the activation of sirtuin-1 (Sirt1) by both increased provision of $\mathrm{NAD}^{+}$cofactor and activatory phosphorylation by PKA. The activation of Sirt1 and AMPK may also contribute to the correction of insulin resistance by Glo1 inducer. The activation of AMPK is considered to mediate the health-beneficial effects of exercise and caloric restriction, and to contribute to the mechanism of action of metformin - a widely used drug in the treatment of T2DM [137,138]. Metformin is not a competent activator of Nrf2 clinically: the peak plasma 
concentration of metformin is ca. $20 \mu \mathrm{M}$, whereas the activation of Nrf2 by metformin occurs in the concentration range of 600-2700 $\mu \mathrm{M}[139,140]$. Metformin improves dysglycemia in patients with T2DM mainly by decreasing hepatic glucose production [141]. This is likely through a PKA-dependent mechanism [142], as well as through some improvement in the insulin sensitivity of peripheral tissues by mechanisms that remain unclear [143]. It is interesting to speculate that, through the improvement of dysglycemia, metformin may decrease HK2-linked unscheduled glycolysis and thereby contribute to partial improvement in insulin resistance and the prevention of the vascular complications of diabetes. As an indication of its ability to decrease metabolic dysfunction and its likely activation of the UPR, metformin decreased plasma MG concentration in patients with T2DM [144].

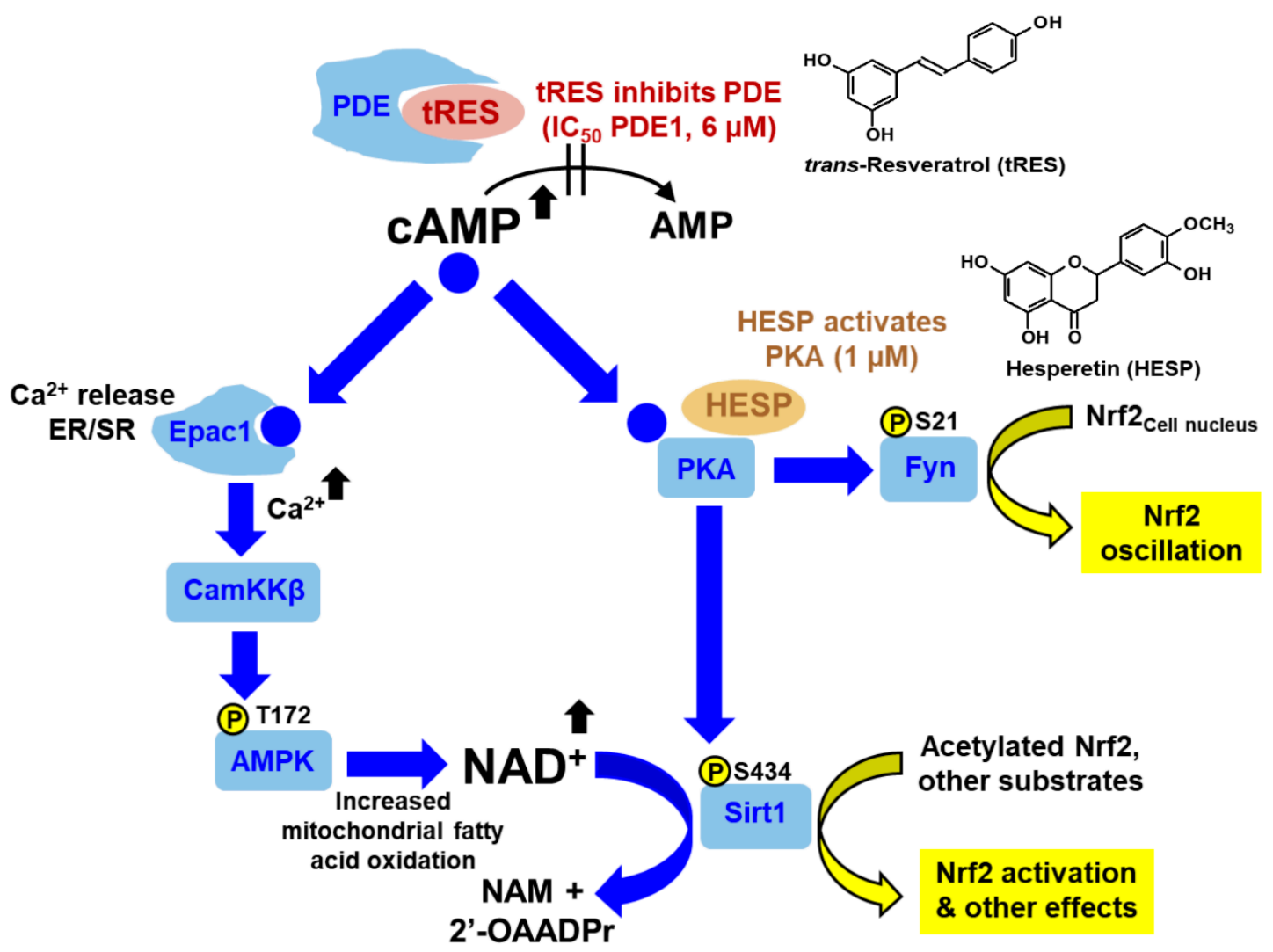

Figure 3. Putative upstream mechanism for activation of transcription factor Nrf2 by tRES-HESP. Abbreviations: AMPK; AMP-dependent kinase; CamKKß, calcium/calmodulin-dependent protein kinase kinase-beta; Epac1, exchange protein directly activated by cAMP 1; ER, endoplasmic reticulum; Fyn, NAM, nicotinamide; 2'-OAADPr, 2'-Oacetyl-ADP-ribose; PDE, cAMP phosphodiesterase; PKA, protein kinase A; sirt1; sirtuin-1; and SR, sarcoplasmic reticulum.

\section{Concluding Remarks}

HK2-linked glycolytic overload and unscheduled glycolysis offers an improved hypothesis to explain metabolic dysfunction contributing to the development of insulin resistance and the vascular complications of diabetes. A dietary supplement treatment, tRES-HESP, has already been developed and evaluated to exploit this hypothesis with beneficial effects in overweight and obese subjects in correcting insulin resistance and improving dysglycemia and vascular inflammation [44,129]. Further studies are now required to evaluate tRES-HESP for the prevention and early-stage reversal of T2DM and the treatment of the vascular complications of diabetes.

Funding: This research was funded by the Qatar Foundation, grant number QB14 (PJT) and Qatar University, grant number QU ERG-CMED-2020-1 (NR). 
Institutional Review Board Statement: Not applicable.

Informed Consent Statement: Not applicable.

Data Availability Statement: Data sharing is not applicable to this article.

Acknowledgments: We thank the Qatar Foundation and Qatar University for funding for our research programs.

Conflicts of Interest: The authors declare no conflict of interest.

\begin{abstract}
Abbreviations
AMPK, AMP-activated protein kinase; ARE, antioxidant response element; ChRE, carbohydrate response element; ChREBP, carbohydrate response element binding protein; CNS, central nervous system; DHAP, dihydroxyacetonephosphate; DS, dicarbonyl stress; F6P, fructose-6-phosphate; FPG, fasting plasma glucose; GA3P, glyceraldehyde-3-phosphate; GA3PD, glyceraldehyde-3-phosphate dehydrogenase; Glo1, glyoxalase 1; G6P, glucose-6-phosphate; G6PD, glucose-6-phosphate dehydrogenase; HFD, high fat diet; HK1, hexokinase-1; HK2, hexokinase-2; HP, hexosamine pathway; HSC70, heat shock protein cognate 70; IRE1 $\alpha$, inositol requiring enzyme- $1 \alpha$; MCT 1-4, monocarboxylate transporters 1-4; MD, mitochondrial dysfunction; NOS3, endothelial nitric oxide synthase; NOX, NADPH oxidase; OS, oxidative stress; PDE, phosphodiesterase; PDLF, periodontal ligament fibroblasts; PFK, phosphofructokinase; PKA, protein kinase A; PKC, protein kinase C; T1DM, type 1 diabetes mellitus; T2DM, type 2 diabetes mellitus; tRES-HESP, trans-resveratrol and hesperetin combination; ROS, reactive oxygen species; SET7/9, histone H3 lysine 4 methyltransferase; Sirt1, sirtuin-1; TXNIP, thioredoxin interacting protein; UPR, unfolded protein response; VDAC, voltage dependent anion channel protein; XBP1, $\mathrm{X}$ box-binding protein 1.
\end{abstract}

\title{
References
}

1. Traut, T. Hexokinase. In Allosteric Regulatory Enzymes; Springer: Boston, MA, USA, 2008; pp. 179-198.

2. Xia, H.-G.; Najafov, A.; Geng, J.; Galan-Acosta, L.; Han, X.; Guo, Y.; Shan, B.; Zhang, Y.; Norberg, E.; Zhang, T.; et al. Degradation of HK2 by chaperone-mediated autophagy promotes metabolic catastrophe and cell death. J. Cell Biol. 2015, 210, 705-716. [CrossRef] [PubMed]

3. John, S.; Weiss, J.N.; Ribalet, B. Subcellular Localization of Hexokinases I and II Directs the Metabolic Fate of Glucose. PLoS ONE 2011, 6, e17674. [CrossRef]

4. Ritov, V.B.; Kelley, D.E. Hexokinase Isozyme Distribution in Human Skeletal Muscle. Diabetes 2001, 50, 1253-1262. [CrossRef]

5. Bryan, N.; Raisch, K.P. Identification of a mitochondrial-binding site on the N-terminal end of hexokinase II. Biosci. Rep. 2015, 35, e00205. [CrossRef]

6. Pedersen, P.L. Voltage dependent anion channels (VDACs): A brief introduction with a focus on the outer mitochondrial compartment's roles together with hexokinase-2 in the "Warburg effect" in cancer. J. Bioenerg. Biomembr. 2008, 40, 123-126. [CrossRef] [PubMed]

7. Wolf, A.; Agnihotri, S.; Munoz, D.; Guha, A. Developmental profile and regulation of the glycolytic enzyme hexokinase 2 in normal brain and glioblastoma multiforme. Neurobiol. Dis. 2011, 44, 84-91. [CrossRef] [PubMed]

8. Hogan, A.; Heyner, S.; Charron, M.J.; Copeland, N.G.; Gilbert, D.J.; Jenkins, N.A.; Thorens, B.; Schultz, G.A. Glucose transporter gene expression in early mouse embryos. Development 1991, 113, 363-372. [CrossRef]

9. Yu, L.; Chen, X.; Sun, X.; Wang, L.; Chen, S. The Glycolytic Switch in Tumors: How Many Players Are Involved? J. Cancer 2017, 8, 3430-3440. [CrossRef] [PubMed]

10. Mitsuishi, Y.; Taguchi, K.; Kawatani, Y.; Shibata, T.; Nukiwa, T.; Aburatani, H.; Yamamoto, M.; Motohashi, H. Nrf2 redirects glucose and glutamine into anabolic pathways in metabolic reprogramming. Cancer Cell 2012, 22, 66-79. [CrossRef]

11. Rempel, A.; Mathupala, S.P.; Pedersen, P.L. Glucose catabolism in cancer cells: Regulation of the type II hexokinase promoter by glucose and cyclic AMP. FEBS Lett. 1996, 385, 233-237. [CrossRef]

12. Mathupala, S.P.; Rempel, A.; Pedersen, P.L. Glucose Catabolism in Cancer Cells: Isolation, sequence, and activity of the promoter for type II hexokinase. J. Biol. Chem. 1995, 270, 16918-16925. [CrossRef] [PubMed]

13. Irshad, Z.; Xue, M.; Ashour, A.; Larkin, J.R.; Thornalley, P.J.; Rabbani, N. Activation of the unfolded protein response in high glucose treated endothelial cells is mediated by methylglyoxal. Sci. Rep. 2019, 9, 7889. [CrossRef]

14. Laakso, M.; Malkki, M.; Kekäläinen, P.; Kuusisto, J.; Deeb, S.S. Polymorphisms of the human hexokinase II gene: Lack of association with NIDDM and insulin resistance. Diabetologia 1995, 38, 617-622. [CrossRef] [PubMed] 
15. Lehto, M.; Huang, X.; Davis, E.M.; Le Beau, M.M.; Laurila, E.; Eriksson, K.F.; Bell, G.I.; Groop, L. Human hexokinase II gene: Exon-intron organization, mutation screening in NIDDM, and its relationship to muscle hexokinase activity. Diabetologia 1995 38, 1466-1474. [CrossRef] [PubMed]

16. Ardehali, H.; Tiller, G.E.; Printz, R.L.; Mochizuki, H.; Prochazka, M.; Granner, D.K. A novel (TA)n polymorphism in the hexokinase II gene: Application to noninsulin-dependent diabetes mellitus in the Pima Indians. Hum. Genet. 1996, 97, 482-485. [CrossRef] [PubMed]

17. Ashour, A.; Xue, M.; Al-Motawa, M.; Thornalley, P.J.; Rabbani, N. Glycolytic overload-driven dysfunction of periodontal ligament fibroblasts in high glucose concentration, corrected by glyoxalase 1 inducer. BMJ Open Diabetes Res. Care 2020, 8 , e001458. [CrossRef] [PubMed]

18. Viticchiè, G.; Agostini, M.; Lena, A.M.; Mancini, M.; Zhou, H.; Zolla, L.; Dinsdale, D.; Saintigny, G.; Melino, G.; Candi, E. p63 supports aerobic respiration through hexokinase II. Proc. Natl. Acad. Sci. USA 2015, 112, 11577-11582. [CrossRef] [PubMed]

19. Nishikawa, T.; Edelstein, D.; Liang Du, X.; Yamagishi, S.; Matsumura, T.; Kaneda, Y.; Yorek, M.A.; Beede, D.; Oates, P.J.; Hammes, H.P.; et al. Normalizing mitochondrial superoxide production blocks three pathways of hyperglycaemia damage. Nature 2000, 404, 787-790. [CrossRef]

20. Xue, M.; Qian, Q.; Adaikalakoteswari, A.; Rabbani, N.; Babaei-Jadidi, R.; Thornalley, P.J. Activation of NF-E2-Related Factor-2 Reverses Biochemical Dysfunction of Endothelial Cells Induced by Hyperglycemia Linked to Vascular Disease. Diabetes 2008, 57, 2809-2817. [CrossRef]

21. Quijano, C.; Castro, L.; Peluffo, G.; Valez, V.; Radi, R. Enhanced mitochondrial superoxide in hyperglycemic endothelial cells: Direct measurements and formation of hydrogen peroxide and peroxynitrite. AJP-Heart Circ. Physiol. 2007, 293, H3404-H3414 [CrossRef]

22. Noguchi, R.; Kubota, H.; Yugi, K.; Toyoshima, Y.; Komori, Y.; Soga, T.; Kuroda, S. The selective control of glycolysis, gluconeogenesis and glycogenesis by temporal insulin patterns. Mol. Syst. Biol. 2013, 9, 664. [CrossRef]

23. Printz, R.L.; Koch, S.; Potter, L.R.; O’Doherty, R.M.; Tiesinga, J.J.; Moritz, S.; Granner, D.K. Hexokinase II mRNA and gene structure, regulation by insulin, and evolution. J. Biol. Chem. 1993, 268, 5209-5219. [CrossRef]

24. Osawa, H.; Sutherland, C.; Robey, R.B.; Printz, R.L.; Granner, D.K. Analysis of the Signaling Pathway Involved in the Regulation of Hexokinase II Gene Transcription by Insulin. J. Biol. Chem. 1996, 271, 16690-16694. [CrossRef] [PubMed]

25. Probst, I.; Unthan-Fechner, K. Activation of glycolysis by insulin with a sequential increase of the 6-phosphofructo-2-kinase activity, fructose-2,6-bisphosphate level and pyruvate kinase activity in cultured rat hepatocytes. Eur. J. Biochem. 1985, 153, 347-353. [CrossRef] [PubMed]

26. Nasrin, N.; Ercolani, L.; Denaro, M.; Kong, X.F.; Kang, I.; Alexander, M. An insulin response element in the glyceraldehyde-3phosphate dehydrogenase gene binds a nuclear protein induced by insulin in cultured cells and by nutritional manipulations in vivo. Proc. Natl. Acad. Sci. USA 1990, 87, 5273-5277. [CrossRef] [PubMed]

27. Sans, C.L.; Satterwhite, D.J.; Stoltzman, C.A.; Breen, K.T.; Ayer, D.E. MondoA-Mlx Heterodimers Are Candidate Sensors of Cellular Energy Status: Mitochondrial Localization and Direct Regulation of Glycolysis. Mol. Cell. Biol. 2006, $26,4863-4871$. [CrossRef] [PubMed]

28. Jeong, Y.S.; Kim, D.; Lee, Y.S.; Kim, H.J.; Han, J.Y.; Im, S.S.; Chong, H.K.; Kwon, J.K.; Cho, Y.H.; Kim, W.K.; et al. Integrated Expression Profiling and Genome-Wide Analysis of ChREBP Targets Reveals the Dual Role for ChREBP in Glucose-Regulated Gene Expression. PLoS ONE 2011, 6, e22544.

29. Ma, L.; Robinson, L.N.; Towle, H.C. ChREBP•Mlx Is the Principal Mediator of Glucose-induced Gene Expression in the Liver. J. Biol. Chem. 2006, 281, 28721-28730. [CrossRef]

30. Arden, C.; Tudhope, S.J.; Petrie, J.L.; Al-Oanzi, Z.H.; Cullen, K.S.; Lange, A.J.; Towle, H.C.; Agius, L. Fructose 2,6-bisphosphate is essential for glucose-regulated gene transcription of glucose-6-phosphatase and other ChREBP target genes in hepatocytes. Biochem. J. 2012, 443, 111-123. [CrossRef]

31. Rabbani, N.; Thornalley, P.J. Hexokinase-2 Glycolytic Overload in Diabetes and Ischemia-Reperfusion Injury. Trends Endocrinol. Metab. 2019, 30, 419-431. [CrossRef]

32. Brownlee, M. Biochemistry and molecular cell biology of diabetic complications. Nature 2001, 414, 813-820. [CrossRef] [PubMed]

33. Hink, U.; Li, H.; Mollnau, H.; Oelze, M.; Matheis, E.; Hartmann, M.; Skatchkov, M.; Thaiss, F.; Stahl, R.A.K.; Warnholtz, A.; et al. Mechanisms underlying endothelial dysfunction in diabetes mellitus. Circ. Res. 2001, 88, 14-22. [CrossRef] [PubMed]

34. Guzik, T.J.; Mussa, S.; Gastaldi, D.; Sadowski, J.; Ratnatunga, C.; Pillai, R.; Channon, K.M. Mechanisms of Increased Vascular Superoxide Production in Human Diabetes Mellitus: Role of NAD(P)H Oxidase and Endothelial Nitric Oxide Synthase. Circulation 2002, 105, 1656-1662. [CrossRef] [PubMed]

35. Brandes, R.P.; Kreuzer, J. Vascular NADPH oxidases: Molecular mechanisms of activation. Cardiovasc. Res. 2005, 65, 16-27. [CrossRef]

36. Lonn, E.; Yusuf, S.; Hoogwerf, B.; Pogue, J.; Yi, Q.L.; Zinman, B.; Bosch, J.; Dagenais, G.; Mann, J.F.E.; Gerstein, H.C. Effects of vitamin E on cardiovascular and microvascular outcomes in high-risk patients with diabetes—Results of the HOPE study and MICRO-HOPE substudy. Diabetes Care 2002, 25, 1919-1927. [CrossRef]

37. Han, T.; Bai, J.; Liu, W.; Hu, Y. A systematic review and meta-analysis of $\alpha$-lipoic acid in the treatment of diabetic peripheral neuropathy. Eur. J. Endocrinol. 2012, 167, 465-471. [CrossRef] 
38. Karachalias, N.; Babaei-Jadidi, R.; Rabbani, N.; Thornalley, P.J. Increased protein damage in renal glomeruli, retina, nerve, plasma and urine and its prevention by thiamine and benfotiamine therapy in a rat model of diabetes. Diabetologia 2010, 53, 1506-1516. [CrossRef]

39. Feldman, E.L.; Callaghan, B.C.; Pop-Busui, R.; Zochodne, D.W.; Wright, D.E.; Bennett, D.L.; Bril, V.; Russell, J.W.; Viswanathan, V. Diabetic neuropathy. Nat. Rev. Dis. Primers 2019, 5, 41. [CrossRef]

40. Gardiner, N.J.; Wang, Z.; Luke, C.; Gott, A.; Price, S.A.; Fernyhough, P. Expression of hexokinase isoforms in the dorsal root ganglion of the adult rat and effect of experimental diabetes. Brain Res. 2007, 1175 (Suppl. C), 143-154. [CrossRef]

41. Kim, E.S.; Isoda, F.; Kurland, I.; Mobbs, C.V. Glucose-Induced Metabolic Memory in Schwann Cells: Prevention by PPAR Agonists. Endocrinology 2013, 154, 3054-3066. [CrossRef]

42. Pan, S.; Chan, J.R. Regulation and dysregulation of axon infrastructure by myelinating glia. J. Cell Biol. 2017, 216, 3903-3916. [CrossRef]

43. Xue, M.; Rabbani, N.; Momiji, H.; Imbasi, P.; Anwar, M.M.; Kitteringham, N.R.; Park, B.K.; Souma, T.; Moriguchi, T.; Yamamoto, M.; et al. Transcriptional control of glyoxalase 1 by Nrf2 provides a stress responsive defence against dicarbonyl glycation. Biochem. J. 2012, 443, 213-222. [CrossRef] [PubMed]

44. Xue, M.; Weickert, M.O.; Qureshi, S.; Ngianga-Bakwin, K.; Anwar, A.; Waldron, M.; Shafie, A.; Messenger, D.; Fowler, M.; Jenkins, G.; et al. Improved glycemic control and vascular function in overweight and obese subjects by glyoxalase 1 inducer formulation. Diabetes 2016, 65, 2282-2294. [CrossRef] [PubMed]

45. Iori, E.; Millioni, R.; Puricelli, L.; Arrigoni, G.; Lenzini, L.; Trevisan, R.; James, P.; Rossi, G.P.; Pinna, L.A.; Tessari, P. Glycolytic enzyme expression and pyruvate kinase activity in cultured fibroblasts from type 1 diabetic patients with and without nephropathy. Biochim. Biophys. Acta (BBA)—Mol. Basis Dis. 2008, 1782, 627-633. [CrossRef] [PubMed]

46. Isoe, T.; Makino, Y.; Mizumoto, K.; Sakagami, H.; Fujita, Y.; Honjo, J.; Takiyama, Y.; Itoh, H.; Haneda, M. High glucose activates HIF-1-mediated signal transduction in glomerular mesangial cells through a carbohydrate response element binding protein. Kidney Intern. 2010, 78, 48-59. [CrossRef] [PubMed]

47. Beemer, F.A.; Vlug, A.M.C.; Rijksen, G.; Hamburg, A.; Staal, G.E.J. Characterization of Some Glycolytic Enzymes from Human Retina and Retinoblastoma. Cancer Res. 1982, 42, 4228-4232. [PubMed]

48. Magnani, P.; Cherian, P.V.; Gould, G.W.; Greene, D.A.; Sima, A.A.F.; Brosius, F.C., III. Glucose transporters in rat peripheral nerve: Paradonal expression of GLUT1 and GLUT3. Metabolism 1996, 45, 1466-1473. [CrossRef]

49. Echave, P.; Machado-da-Silva, G.; Arkell, R.S.; Duchen, M.R.; Jacobson, J.; Mitter, R.; Lloyd, A.C. Extracellular growth factors and mitogens cooperate to drive mitochondrial biogenesis. J. Cell Sci. 2009, 122, 4516-4525. [CrossRef]

50. Segev, H.; Fishman, B.; Schulman, R.; Itskovitz-Eldor, J. The Expression of the Class 1 Glucose Transporter Isoforms in Human Embryonic Stem Cells, and the Potential Use of GLUT2 as a Marker for Pancreatic Progenitor Enrichment. Stem Cells Dev. 2012, 21, 1653-1661. [CrossRef]

51. Johnson, M.T.; Mahmood, S.; Patel, M.S. Intermediary Metabolism and Energetics during Murine Early Embryogenesis. J. Biol. Chem. 2003, 278, 31457-31460. [CrossRef]

52. Yang, X.; Håkan Borg, L.A.; Eriksson, U.J. Altered mitochondrial morphology of rat embryos in diabetic pregnancy. Anat. Rec. 1995, 241, 255-267. [CrossRef] [PubMed]

53. Eriksson, U.J.; Wentzel, P.; Minhas, H.S.; Thornalley, P.J. Teratogenicity of 3-deoxyglucosone and diabetic embryopathy. Diabetes 1998, 47, 1960-1966. [CrossRef]

54. Horal, M.; Zhang, Z.; Stanton, R.; Virkamäki, A.; Loeken, M.R. Activation of the hexosamine pathway causes oxidative stress and abnormal embryo gene expression: Involvement in diabetic teratogenesis. Birth Defects Res. Part A Clin. Mol. Teratol. 2004, 70, 519-527. [CrossRef]

55. Hiramatsu, Y.; Sekiguchi, N.; Hayashi, M.; Isshiki, K.; Yokota, T.; King, G.L.; Loeken, M.R. Diacylglycerol Production and Protein Kinase C Activity Are Increased in a Mouse Model of Diabetic Embryopathy. Diabetes 2002, 51, 2804-2810. [CrossRef] [PubMed]

56. Singleton, J.R.; Smith, A.G.; Russell, J.W.; Feldman, E.L. Microvascular Complications of Impaired Glucose Tolerance. Diabetes 2003, 52, 2867-2873. [CrossRef] [PubMed]

57. Silva, C.M.; Arnegard, M.E.; Maric-Bilkan, C. Dysglycemia in Pregnancy and Maternal/Fetal Outcomes. J. Women's Health 2021, 30, 187-193. [CrossRef]

58. Lefort, N.; Glancy, B.; Bowen, B.; Willis, W.T.; Bailowitz, Z.; De Filippis, E.A.; Brophy, C.; Meyer, C.; Højlund, K.; Yi, Z.; et al. Increased Reactive Oxygen Species Production and Lower Abundance of Complex I Subunits and Carnitine Palmitoyltransferase 1B Protein Despite Normal Mitochondrial Respiration in Insulin-Resistant Human Skeletal Muscle. Diabetes 2010, 59, 2444-2452. [CrossRef] [PubMed]

59. Yki-Järvinen, H.; Daniels, M.C.; Virkamäki, A.; Mäkimattila, S.; DeFronzo, R.A.; McClain, D. Increased Glutamine: Fructose-6Phosphate Amidotransferase Activity in Skeletal Muscle of Patients With NIDDM. Diabetes 1996, 45, 302-307. [CrossRef]

60. Li, M.; Vienberg, S.G.; Bezy, O.; O’Neill, B.T.; Kahn, C.R. Role of PKC $\delta$ in Insulin Sensitivity and Skeletal Muscle Metabolism. Diabetes 2015, 64, 4023-4032. [CrossRef]

61. Mey, J.T.; Blackburn, B.K.; Miranda, E.R.; Chaves, A.B.; Briller, J.; Bonini, M.G.; Haus, J.M. Dicarbonyl stress and glyoxalase enzyme system regulation in human skeletal muscle. Am. J. Physiol. Regul. Integr. Comp. Physiol. 2018, 314, R181-R190. [CrossRef]

62. Pendergrass, M.; Koval, J.; Vogt, C.; Yki-Jarvinen, H.; Iozzo, P.; Pipek, R.; Ardehali, H.; Printz, R.; Granner, D.; DeFronzo, R.A. Insulin-Induced hexokinase II expression is reduced in obesity and NIDDM. Diabetes 1998, 47, 387-394. [CrossRef] 
63. Lavis, V.R. Hexokinase isozymes of normal human subcutaneous adipose tissue. Metabolism 1978, 27, 1101-1108. [CrossRef]

64. Masania, J.; Malczewska-Malec, M.; Razny, U.; Goralska, J.; Zdzienicka, A.; Kiec-Wilk, B.; Gruca, A.; Stancel-Mozwillo, J.; Dembinska-Kiec, A.; Rabbani, N.; et al. Dicarbonyl stress in clinical obesity. Glycoconj. J. 2016, 33, 581-589. [CrossRef]

65. Fazakerley, D.J.; Minard, A.Y.; Krycer, J.R.; Thomas, K.C.; Stöckli, J.; Harney, D.J.; Burchfield, J.G.; Maghzal, G.J.; Caldwell, S.T.; Hartley, R.C.; et al. Mitochondrial oxidative stress causes insulin resistance without disrupting oxidative phosphorylation. J. Biol. Chem. 2018, 293, 7315-7328. [CrossRef]

66. Brandon, A.E.; Liao, B.M.; Diakanastasis, B.; Parker, B.L.; Raddatz, K.; McManus, S.A.; O’Reilly, L.; Kimber, E.; van der Kraan, A.G.; Hancock, D.; et al. Protein Kinase C Epsilon Deletion in Adipose Tissue, but Not in Liver, Improves Glucose Tolerance. Cell Metab. 2019, 29, 183-191.e7. [CrossRef]

67. Morton, N.M.; Nelson, Y.B.; Michailidou, Z.; Di Rollo, E.M.; Ramage, L.; Hadoke, P.W.F.; Seckl, J.R.; Bunger, L.; Horvat, S.; Kenyon, C.J.; et al. A stratified transcriptomics analysis of polygenic fat and lean mouse adipose tissues identifies novel candidate obesity genes. PLoS ONE 2011, 6, e23944. [CrossRef]

68. Komolafe, O.A.; Ofusori, D.A.; Adewole, O.S.; Ayoka, A.O.; Bejide, R. Histological and Histochemical Studies of the Aorta and Pulmonary Trunk in STZ-induced Diabetic Wistar Rats Treated with Momordica charantia. Int. J. Morphol. 2013, $31,716-723$. [CrossRef]

69. Kang, J.; Dai, X.-S.; Yu, T.-B.; Wen, B.; Yang, Z.-W. Glycogen accumulation in renal tubules, a key morphological change in the diabetic rat kidney. Acta Diabetol. 2005, 42, 110-116. [CrossRef]

70. Geoffrion, M.; Du, X.; Irshad, Z.; Vanderhyden, B.C.; Courville, K.; Sui, G.; D'Agati, V.D.; Ott-Braschi, S.; Rabbani, N.; Thornalley, P.J.; et al. Differential effects of glyoxalase 1 overexpression on diabetic atherosclerosis and renal dysfunction in streptozotocin-treated, apolipoprotein E-deficient mice. Physiol. Rep. 2014, 2, e12043. [CrossRef]

71. Fantus, I.G.; Goldberg, H.J.; Whiteside, C.I.; Topic, D. The Hexosamine Biosynthesis Pathway. In The Diabetic Kidney; Cortes, P., Mogensen, C.E., Eds.; Humana Press: Totowa, NJ, USA, 2006; pp. 117-133.

72. Kiritoshi, S.; Nishikawa, T.; Sonoda, K.; Kukidome, D.; Senokuchi, T.; Matsuo, T.; Matsumura, T.; Tokunaga, H.; Brownlee, M.; Araki, E. Reactive oxygen species from mitochondria Induce cyclooxygenase-2 gene expression in human mesangial cells: Potential role in diabetic nephropathy. Diabetes 2003, 52, 2570-2577. [CrossRef]

73. Shiba, T.; Inoguchi, T.; Sportsman, J.R.; Heath, W.F.; Bursell, S.; King, G.L. Correlation of diacylglycerol level and protein kinase C activity in rat retina to retinal circulation. Am. J. Physiol. 1993, 265, E783-E793. [CrossRef]

74. Powell, H.C.; Rosoff, J.; Myers, R.R. Microangiopathy in human diabetic neuropathy. Acta Neuropathol. 1985, 68, 295-305. [CrossRef]

75. Bierhaus, A.; Fleming, T.; Stoyanov, S.; Leffler, A.; Babes, A.; Neacsu, C.; Sauer, S.K.; Eberhardt, M.; Schnolzer, M.; Lasischka, F.; et al. Methylglyoxal modification of Nav1.8 facilitates nociceptive neuron firing and causes hyperalgesia in diabetic neuropathy. Nat. Med. 2012, 18, 926-933. [CrossRef]

76. Zhang, L.; Yu, C.; Vasquez, F.E.; Galeva, N.; Onyango, I.; Swerdlow, R.H.; Dobrowsky, R.T. Hyperglycemia alters the schwann cell mitochondrial proteome and decreases coupled respiration in the absence of superoxide production. J. Proteome Res. 2010, 9 , 458-471. [CrossRef]

77. Russell, J.W.; Berent-Spillson, A.; Vincent, A.M.; Freimann, C.L.; Sullivan, K.A.; Feldman, E.L. Oxidative injury and neuropathy in diabetes and impaired glucose tolerance. Neurobiol. Dis. 2008, 30, 420-429. [CrossRef]

78. Duran-Jimenez, B.; Dobler, D.; Moffatt, S.; Rabbani, N.; Streuli, C.H.; Thornalley, P.J.; Tomlinson, D.R.; Gardiner, N.J. Advanced Glycation Endproducts in extracellular matrix proteins contribute to the failure of sensory nerve regeneration in diabetes. Diabetes 2009, 58, 2893-2903. [CrossRef]

79. Schellini, S.A.; Gregorio, E.A.; Spadella, C.T.; Machado, J.L.M.; Demoraessilva, M.A. Muller cells and diabetic-retinopathy. Braz. J. Med. Biol. Res. 1995, 28, 977-980.

80. Yao, D.; Taguchi, T.; Matsumura, T.; Pestell, R.; Edelstein, D.; Giardino, I.; Suske, G.; Rabbani, N.; Thornalley, P.J.; Sarthy, V.P.; et al. High glucose increases angiopoietin-2 transcription in microvascular endothelial cells through methylglyoxal modification of mSin3A. J. Biol. Chem. 2007, 282, 31038-31045. [CrossRef]

81. Tien, T.; Zhang, J.; Muto, T.; Kim, D.; Sarthy, V.P.; Roy, S. High Glucose Induces Mitochondrial Dysfunction in Retinal Müller Cells: Implications for Diabetic Retinopathy. Investig. Ophthalmol. Vis. Sci. 2017, 58, 2915-2921. [CrossRef]

82. Semba, R.D.; Huang, H.; Lutty, G.A.; Van Eyk, J.E.; Hart, G.W. The role of O-GlcNAc signaling in the pathogenesis of diabetic retinopathy. Proteom. Clin. Appl. 2014, 8, 218-231. [CrossRef]

83. Ellington, S.K.L. Effects of excess glucose on mammalian post-implantation embryos. Int. J. Dev. BioI. 1997, 41, $299-306$.

84. Nannipieri, M.; Lanfranchi, A.; Santerini, D.; Catalano, C.; van de Werve, G.; Ferrannini, E. Influence of Long-Term Diabetes on Renal Glycogen Metabolism in the Rat. Nephron 2001, 87, 50-57. [CrossRef]

85. Salceda, R.; Coffe, V.M.; Hernández-Berrones, J. Glycogen Levels in the Normal and Diabetic Rat Retina. Investig. Ophthalmol. Vis. Sci. 2003, 44, 3879.

86. Yagihashi, S.; Matsunaga, M. Ultrastructural pathology of peripheral nerves in patients with diabetic neuropathy. Tohoku J. Exp. Med. 1979, 129, 357-366. [CrossRef]

87. Moore, S.A.; Peterson, R.G.; Felten, D.L.; O'Connor, B.L. Glycogen accumulation in tibial nerves of experimentally diabetic and aging control rats. J. Neurol. Sci. 1981, 52, 289-303. [CrossRef] 
88. Ishibashi, F.; Kojima, R.; Taniguchi, M.; Kosaka, A.; Uetake, H.; Tavakoli, M. The Expanded Bead Size of Corneal C-Nerve Fibers Visualized by Corneal Confocal Microscopy Is Associated with Slow Conduction Velocity of the Peripheral Nerves in Patients with Type 2 Diabetes Mellitus. J. Diabetes Res. 2016, 2016, 3653459. [CrossRef]

89. Lillioja, S.; Mott, D.M.; Howard, B.V.; Bennett, P.H.; Yki-Järvinen, H.; Freymond, D.; Nyomba, B.L.; Zurlo, F.; Swinburn, B.; Bogardus, C. Impaired glucose tolerance as a disorder of insulin action. Longitudinal and cross-sectional studies in Pima Indians. N. Engl. J. Med. 1988, 318, 1217-1225. [CrossRef]

90. Warram, J.H.; Martin, B.C.; Krolewski, A.S.; Soeldner, J.S.; Kahn, C.R. Slow glucose removal rate and hyperinsulinemia precede the development of type II diabetes in the offspring of diabetic parents. Ann. Intern. Med. 1990, 113, 909-915. [CrossRef]

91. DeFronzo, R.A.; Tripathy, D. Skeletal muscle insulin resistance is the primary defect in type 2 diabetes. Diabetes Care 2009, 32 (Suppl. S2), S157-S163. [CrossRef]

92. DeFronzo, R.A.; Hendler, R.; Simonson, D. Insulin Resistance is a Prominent Feature of Insulin-dependent Diabetes. Diabetes 1982, 31, 795-801. [CrossRef]

93. Vogt, C.; Ardehali, H.; Iozzo, P.; Yki-Järvinen, H.; Koval, J.; Maezono, K.; Pendergrass, M.; Printz, R.; Granner, D.; DeFronzo, R.; et al. Regulation of hexokinase II expression in human skeletal muscle in vivo. Metab.—Clin. Exp. 2000, 49, 814-818. [CrossRef]

94. Vogt, C.; Yki-Jarvinen, H.; Iozzo, P.; Pipek, R.; Pendergrass, M.; Koval, J.; Ardehali, H.; Printz, R.; Granner, D.; DeFronzo, R.; et al. Effects of Insulin on Subcellular Localization of Hexokinase II in Human Skeletal Muscle in Vivo. J. Clin. Endocrinol. Metab. 1998, 83, 230-234. [CrossRef] [PubMed]

95. Roberts, D.J.; Tan-Sah, V.P.; Smith, J.M.; Miyamoto, S. Akt phosphorylates HK-II at Thr-473 and increases mitochondrial HK-II association to protect cardiomyocytes. J. Biol. Chem. 2013, 288, 23798-23806. [CrossRef] [PubMed]

96. Vestergaard, H.; Bjørbaek, C.; Hansen, T.; Larsen, F.S.; Granner, D.K.; Pedersen, O. Impaired activity and gene expression of hexokinase II in muscle from non-insulin-dependent diabetes mellitus patients. J. Clin. Investig. 1995, 96, 2639-2645. [CrossRef] [PubMed]

97. DeFronzo, R.A.; Jacot, E.; Jequier, E.; Maeder, E.; Wahren, J.; Felber, J.P. The Effect of Insulin on the Disposal of Intravenous Glucose: Results from Indirect Calorimetry and Hepatic and Femoral Venous Catheterization. Diabetes 1981, 30, $1000-1007$. [CrossRef] [PubMed]

98. Pedersen, O.; Bak, J.F.; Andersen, P.H.; Lund, S.; Moller, D.E.; Flier, J.S.; Kahn, B.B. Evidence against altered expression of GLUT1 or GLUT4 in skeletal muscle of patients with obesity or NIDDM. Diabetes 1990, 39, 865-870. [CrossRef] [PubMed]

99. Ciaraldi, T.P.; Mudaliar, S.; Barzin, A.; Macievic, J.A.; Edelman, S.V.; Park, K.S.; Henry, R.R. Skeletal Muscle GLUT1 Transporter Protein Expression and Basal Leg Glucose Uptake Are Reduced in Type 2 Diabetes. J. Clin. Endocrinol. Metab. 2005, 90, 352-358. [CrossRef] [PubMed]

100. Marshall, B.A.; Ren, J.M.; Johnson, D.W.; Gibbs, E.M.; Lillquist, J.S.; Soeller, W.C.; Holloszy, J.O.; Mueckler, M. Germline manipulation of glucose homeostasis via alteration of glucose transporter levels in skeletal muscle. J. Biol. Chem. 1993, 268, 18442-18445. [CrossRef]

101. Gulve, E.A.; Ren, J.M.; Marshall, B.A.; Gao, J.; Hansen, P.A.; Holloszy, J.O.; Mueckler, M. Glucose transport activity in skeletal muscles from transgenic mice overexpressing GLUT1. Increased basal transport is associated with a defective response to diverse stimuli that activate GLUT4. J. Biol. Chem. 1994, 269, 18366-18370. [CrossRef]

102. Buse, M.G.; Robinson, K.A.; Marshall, B.A.; Hresko, R.C.; Mueckler, M.M. Enhanced O-GlcNAc protein modification is associated with insulin resistance in GLUT1-overexpressing muscles. Am. J. Physiol. Endocrinol. Metab. 2002, 283, E241-E250. [CrossRef]

103. Fazakerley, D.J.; Krycer, J.R.; Kearney, A.L.; Hocking, S.L.; James, D.E. Muscle and adipose tissue insulin resistance: Malady without mechanism? J. Lipid Res. 2019, 60, 1720-1732. [CrossRef] [PubMed]

104. Hansen, P.A.; Gulve, E.A.; Marshall, B.A.; Gao, J.; Pessin, J.E.; Holloszy, J.O.; Mueckler, M. Skeletal muscle glucose transport and metabolism are enhanced in transgenic mice overexpressing the Glut4 glucose transporter. J. Biol. Chem. 1995, 270, 1679-1684. [CrossRef]

105. Heikkinen, S.; Pietilä, M.; Halmekytö, M.; Suppola, S.; Pirinen, E.; Deeb, S.S.; Jänne, J.; Laakso, M. Hexokinase II-deficient mice: Prenatal death of homozygotes without disturbances in glucose tolerance in heterozygotes. J. Biol. Chem. 1999, 274, 22517-22523. [CrossRef] [PubMed]

106. Chang, P.Y.; Jensen, J.; Printz, R.L.; Granner, D.K.; Ivy, J.L.; Moller, D.E. Overexpression of hexokinase II in transgenic mice Evidence that increased phosphorylation augments muscle glucose uptake. J. Biol. Chem. 1996, 271, 14834-14839. [CrossRef] [PubMed]

107. Fueger, P.T.; Bracy, D.P.; Malabanan, C.M.; Pencek, R.R.; Granner, D.K.; Wasserman, D.H. Hexokinase II overexpression improves exercise-stimulated but not insulin-stimulated muscle glucose uptake in high-fat-fed C57BL/6J mice. Diabetes 2004, 53, 306-314. [CrossRef]

108. Hansen, P.A.; Marshall, B.A.; Chen, M.; Holloszy, J.O.; Mueckler, M. Transgenic Overexpression of Hexokinase II in Skeletal Muscle Does Not Increase Glucose Disposal in Wild-type or Glut1-overexpressing Mice. J. Biol. Chem. 2000, 275, 22381-22386. [CrossRef]

109. Thiebaud, D.; Jacot, E.; Defronzo, R.A.; Maeder, E.; Jequier, E.; Felber, J.-P. The Effect of Graded Doses of Insulin on Total Glucose Uptake, Glucose Oxidation, and Glucose Storage in Man. Diabetes 1982, 31, 957-963. [CrossRef] 
110. Ceperuelo-Mallafré, V.; Ejarque, M.; Serena, C.; Duran, X.; Montori-Grau, M.; Rodríguez, M.A.; Yanes, O.; Núñez-Roa, C.; Roche, K.; Puthanveetil, P.; et al. Adipose tissue glycogen accumulation is associated with obesity-linked inflammation in humans. Mol. Metab. 2016, 5, 5-18. [CrossRef]

111. Ebeling, P.; Koistinen, H.A.; Koivisto, V.A. Insulin-independent glucose transport regulates insulin sensitivity. FEBS Lett. 1998, 436, 301-303. [CrossRef]

112. Stoltzman, C.A.; Peterson, C.W.; Breen, K.T.; Muoio, D.M.; Billin, A.N.; Ayer, D.E. Glucose sensing by MondoA:Mlx complexes: A role for hexokinases and direct regulation of thioredoxin-interacting protein expression. Proc. Natl. Acad. Sci. USA 2008, 105, 6912-6917. [CrossRef]

113. Ahn, B.; Soundarapandian, M.M.; Sessions, H.; Peddibhotla, S.; Roth, G.P.; Li, J.-L.; Sugarman, E.; Koo, A.; Malany, S.; Wang, M.; et al. MondoA coordinately regulates skeletal myocyte lipid homeostasis and insulin signaling. J. Clin. Investig. 2016, 126, 3567-3579. [CrossRef] [PubMed]

114. Ahn, B.; Wan, S.; Jaiswal, N.; Vega, R.B.; Ayer, D.E.; Titchenell, P.M.; Han, X.; Won, K.J.; Kelly, D.P. MondoA drives muscle lipid accumulation and insulin resistance. JCI Insight 2019, 5, e129119. [CrossRef] [PubMed]

115. Mozaffary, A.; Asgari, S.; Tohidi, M.; Kazempour-Ardebili, S.; Azizi, F.; Hadaegh, F. Change in fasting plasma glucose and incident type 2 diabetes mellitus: Results from a prospective cohort study. BMJ Open 2016, 6, e010889. [CrossRef]

116. Bock, G.; Chittilapilly, E.; Basu, R.; Toffolo, G.; Cobelli, C.; Chandramouli, V.; Landau, B.R.; Rizza, R.A. Contribution of Hepatic and Extrahepatic Insulin Resistance to the Pathogenesis of Impaired Fasting Glucose: Role of Increased Rates of Gluconeogenesis. Diabetes 2007, 56, 1703-1711. [CrossRef]

117. Kaul, K.; Apostolopoulou, M.; Roden, M. Insulin resistance in type 1 diabetes mellitus. Metabolism 2015, 64, 1629-1639. [CrossRef] [PubMed]

118. Pereira, R.I.; Snell-Bergeon, J.K.; Erickson, C.; Schauer, I.E.; Bergman, B.C.; Rewers, M.; Maahs, D.M. Adiponectin Dysregulation and Insulin Resistance in Type 1 Diabetes. J. Clin. Endocrinol. Metab. 2012, 97, E642-E647. [CrossRef] [PubMed]

119. Rabbani, N.; Xue, M.; Thornalley, P.J. Dicarbonyl stress, protein glycation and the unfolded protein response. Glycoconj. J. 2021, 38, 331-334. [CrossRef] [PubMed]

120. Rabbani, N.; Xue, M.; Thornalley, P.J. Methylglyoxal-induced dicarbonyl stress in aging and disease: First steps towards glyoxalase 1-based treatments. Clin. Sci. 2016, 130, 1677-1696. [CrossRef]

121. Lerner, A.G.; Upton, J.-P.; Praveen, P.V.K.; Ghosh, R.; Nakagawa, Y.; Igbaria, A.; Shen, S.; Nguyen, V.; Backes, B.J.; Heiman, M.; et al. IRE1 $\alpha$ induces thioredoxin-interacting protein to activate the NLRP3 inflammasome and promote programmed cell death under irremediable ER stress. Cell Metab. 2012, 16, 250-264. [CrossRef]

122. Waldhart, A.N.; Dykstra, H.; Peck, A.S.; Boguslawski, E.A.; Madaj, Z.B.; Wen, J.; Veldkamp, K.; Hollowell, M.; Zheng, B.; Cantley, L.C.; et al. Phosphorylation of TXNIP by AKT Mediates Acute Influx of Glucose in Response to Insulin. Cell Rep. 2017, 19, 2005-2013. [CrossRef]

123. Oslowski, C.M.; Hara, T.; O'Sullivan-Murphy, B.; Kanekura, K.; Lu, S.; Hara, M.; Ishigaki, S.; Zhu, L.J.; Hayashi, E.; Hui, S.T.; et al. Thioredoxin-interacting protein mediates ER stress-induced $\beta$ cell death through initiation of the inflammasome. Cell Metab. 2012, 16, 265-273. [CrossRef] [PubMed]

124. Jo, S.H.; Kim, M.Y.; Park, J.M.; Kim, T.H.; Ahn, Y.H. Txnip contributes to impaired glucose tolerance by upregulating the expression of genes involved in hepatic gluconeogenesis in mice. Diabetologia 2013, 56, 2723-2732. [CrossRef] [PubMed]

125. Li, Y.; Reddy, M.A.; Miao, F.; Shanmugam, N.; Yee, J.-K.; Hawkins, D.; Ren, B.; Natarajan, R. Role of the Histone H3 Lysine 4 Methyltransferase, SET7/9, in the Regulation of NF-kB-dependent Inflammatory Genes: Relevance to Diabetes and Inflammation. J. Biol. Chem. 2008, 283, 26771-26781. [CrossRef]

126. Chen, J.; Guo, Y.; Zeng, W.; Huang, L.; Pang, Q.; Nie, L.; Mu, J.; Yuan, F.; Feng, B. ER stress triggers MCP-1 expression through SET7/9-induced histone methylation in the kidneys of db/db mice. Am. J. Physiol.-Ren. Physiol. 2014, 306, F916-F925. [CrossRef] [PubMed]

127. Hotamisligil, G.S. Endoplasmic reticulum stress and the inflammatory basis of metabolic disease. Cell 2010, 140, 900-917. [CrossRef] [PubMed]

128. Hotamisligil, G.S. Mechanisms of TNF-alpha-induced insulin resistance. Exp. Clin. Endocrinol. Diabetes 1999, 107, 119-125. [CrossRef]

129. Rabbani, N.; Xue, M.; Weickert, M.O.; Thornalley, P.J. Reversal of Insulin Resistance in Overweight and Obese Subjects by transResveratrol and Hesperetin Combination—Link to Dysglycemia, Blood Pressure, Dyslipidemia, and Low-Grade Inflammation. Nutrients 2021, 13, 2374. [CrossRef]

130. Parikh, H.; Carlsson, E.; Chutkow, W.A.; Johansson, L.E.; Storgaard, H.; Poulsen, P.; Saxena, R.; Ladd, C.; Schulze, P.C.; Mazzini, M.J.; et al. TXNIP Regulates Peripheral Glucose Metabolism in Humans. PLoS Med. 2007, 4, e158. [CrossRef]

131. Uruno, A.; Yagishita, Y.; Katsuoka, F.; Kitajima, Y.; Nunomiya, A.; Nagatomi, R.; Pi, J.; Biswal, S.S.; Yamamoto, M. Nrf2-Mediated Regulation of Skeletal Muscle Glycogen Metabolism. Mol. Cell. Biol. 2016, 36, 1655-1672. [CrossRef]

132. Park, S.-J.; Ahmad, F.; Philp, A.; Baar, K.; Williams, T.; Luo, H.; Ke, H.; Rehmann, H.; Taussig, R.; Brown, A.L.; et al. Resveratrol Ameliorates Aging-Related Metabolic Phenotypes by Inhibiting cAMP Phosphodiesterases. Cell 2012, 148, 421-433. [CrossRef]

133. Hwang, S.-L.; Lin, J.-A.; Shih, P.-H.; Yeh, C.-T.; Yen, G.-C. Pro-Cellular survival and neuroprotection of citrus flavonoid: The actions of hesperetin in PC12 cells. Food Funct. 2012, 3, 1082-1090. [CrossRef] [PubMed] 
134. Xue, M.; Momiji, H.; Rabbani, N.; Barker, G.; Bretschneider, T.; Shmygol, A.; Rand, D.A.; Thornalley, P.J. Frequency modulated translocational oscillations of Nrf2 mediate the ARE cytoprotective transcriptional response. Antioxid. Redox Signal. 2015, 23, 613-629. [CrossRef] [PubMed]

135. Xue, M.; Momiji, H.; Rabbani, N.; Bretschneider, T.; Rand, D.A.; Thornalley, P.J. Frequency modulated translocational oscillations of Nrf2, a transcription factor functioning like a wireless sensor. Biochem. Soc. Trans. 2015, 43, 669-673. [CrossRef] [PubMed]

136. Gerhart-Hines, Z.; Dominy, J.E.; Blättler, S.M.; Jedrychowski, M.P.; Banks, A.S.; Lim, J.-H.; Chim, H.; Gygi, S.P.; Puigserver, P. The cAMP/PKA pathway rapidly activates SIRT1 to promote fatty acid oxidation independently of changes in NAD(+). Mol. Cell 2011, 44, 851-863. [CrossRef]

137. Steinberg, G.R. Cellular Energy Sensing and Metabolism-Implications for Treating Diabetes: The 2017 Outstanding Scientific Achievement Award Lecture. Diabetes 2018, 67, 169-179. [CrossRef]

138. Rena, G.; Hardie, D.G.; Pearson, E.R. The mechanisms of action of metformin. Diabetologia 2017, 60, 1577-1585. [CrossRef]

139. Martin-Montalvo, A.; Mercken, E.M.; Mitchell, S.J.; Palacios, H.H.; Mote, P.L.; Scheibye-Knudsen, M.; Gomes, A.P.; Ward, T.M.; Minor, R.K.; Blouin, M.J.; et al. Metformin improves healthspan and lifespan in mice. Nat. Commun. 2013, 4, 2192. [CrossRef]

140. Graham, G.G.; Punt, J.; Arora, M.; Day, R.O.; Doogue, M.P.; Duong, J.; Furlong, T.J.; Greenfield, J.R.; Greenup, L.C.; Kirkpatrick, C.M.; et al. Clinical Pharmacokinetics of Metformin. Clin. Pharmacokinet. 2011, 50, 81-98. [CrossRef]

141. Stumvoll, M.; Nurjhan, N.; Perriello, G.; Dailey, G.; Gerich, J.E. Metabolic Effects of Metformin in Non-Insulin-Dependent Diabetes Mellitus. N. Engl. J. Med. 1995, 333, 550-554. [CrossRef]

142. Zhou, G.; Myers, R.; Li, Y.; Chen, Y.; Shen, X.; Fenyk-Melody, J.; Wu, M.; Ventre, J.; Doebber, T.; Fujii, N.; et al. Role of AMP-activated protein kinase in mechanism of metformin action. J. Clin. Investig. 2001, 108, 1167-1174. [CrossRef]

143. Del Prato, S. In search of normoglycaemia in diabetes: Controlling postprandial glucose. Int. J. Obes. 2002, 26, S9-S17. [CrossRef] [PubMed]

144. Beisswenger, P.J.; Howell, S.K.; Touchette, A.; Lal, S.; Szwergold, B.S. Metformin reduces systemic methylglyoxal levels in type 2 diabetes. Diabetes 1999, 48, 198-202. [CrossRef] [PubMed] 